\title{
Publisher Correction: Identification of 371 genetic variants for age at first sex and birth linked to externalising behavior
}

Melinda C. Mills (D), Felix C. Tropf(D), David M. Brazel (D), Natalie van Zuydam, Ahmad Vaez (D), eQTLGen Consortium*, BIOS Consortium*, Human Reproductive Behaviour Consortium*, Tune H. Pers (D), Harold Snieder (D), John R. B. Perry (D), Ken K. Ong (D), Marcel den Hoed (D), Nicola Barban (D) and Felix R. Day (D)

Correction to: Nature Human Behaviour https://doi.org/10.1038/s41562-021-01135-3, published online 1 July 2021.

Owing to a technical problem, the below authors were missing from the author list in the originally published version of this Article. Further, the full information on the authors' participation in the different consortia and the sub groups was also missing. The Article has now been corrected accordingly; the full author list is as per the HTML version of this notice.

\section{BIOS Consortium}

René Pool, Carla J.H. van der Kallen, Ettje F. Tigchelaar, Marian Beekman, Leonard H. van den Berg, P. Mila Jhamai, Michiel van Galen, Peter van 't Hof, Irene Nooren, Matthijs Moed, Martijn Vermaat, Freerk van Dijk, Szymon M. Kielbasa.

\section{Human Reproductive Behaviour Consortium}

Marco Brumat, Oscar Franco, W. David Hill, Ilja M. Nolte, Annette Peters, Gudmar Thorleifsson, Unnur Thorsteinsdottir, Melanie Waldenberger.

${ }^{\star}$ Lists of authors and their affiliations appear online.

Published online: 28 July 2021

https://doi.org/10.1038/s41562-021-01179-5

(c) The Author(s), under exclusive licence to Springer Nature Limited 2021 